\begin{tabular}{ll}
\hline \hline MINING AND METALLURGY INSTITUTE BOR & ISSN: 2334-8836 (Štampano izdanje) \\
UDK: 622 & ISSN: 2406-1395 (Online) \\
\hline \hline
\end{tabular}

UDK: $622.7 .016 / .355(045)=111$

doi:10.5937/MMEB1602041P

Sanja Petrović, Ivana Jovanovic , Dejan Bugarin", Srđana Magdalinović*

\title{
LABORATORY TESTING THE GRINDABILITY OF CARBONATE MINERAL RAW MATERIAL OF THE SITE SPASINA BRDJANI - LIMESTONE SAMPLES ${ }^{* *}$
}

\begin{abstract}
This work presents the results of the Bond work index in a ball mill on samples of carbonate mineral raw material (limestone) of the site Spasina - Brdjani. Value of the Bond Work Index was carried out in a ball mill on six samples of limestone from exploration drill holes. The obtained results indicate that in 4 samples of limestone the value of the Bond Work Index is in the range of 5.9 to $6.4 \mathrm{kWh} / \mathrm{t}$. Higher values of the Bond Work Index are achieved in 2 samples and the same amounts 7.059 and $9.526 \mathrm{kWh} t$. The increased value of the Bond Work Index in these samples of limestone is explained by the presence of white-yellow limestone cores and increased magnesium content.

Keywords: Bond Work Index, limestone
\end{abstract}

\section{INTRODUCTION}

Limestone is among the most widespread carbonate rocks, or the most widespread sedimentary rocks. The explored area Spasina - Brdjani (narrower locality the Prokos hill) is situated at the extreme northeast hills of the mountain Majevica, at a distance of about $20 \mathrm{~km}$ southwest of Bijeljina. The explored belt is covered with carbonate deposits with prominent hills and frequent very steep rock sections (especially in the northern part). The exploration area is limited on the west and north by the rivers Mezgrajica and Janja, on the east rests on a contour of the North landfill, while on the south side is the active open pit Bogutovo Selo.
The site Spasine - Brdjani is characterized by limestone and associated sediments belonging to the Middle Miocene of Central Paratetis - Baden and Sarmatian, then Quaternary formations - deluvial and proluvial sediments.

In the engineering - geological terms, this site is characterized by a complex of carbonate of different physical and mechanical properties. Higher areas are hypsometrically covered by compact rock masses of sand, loose to limestone cores, which in depth lean on a package of compact and loose chalk. In general, these carbonate sediments in terms of stability provide a solid rock mass and belong to the group of stable

\footnotetext{
* Mining and Metallurgy Institute Bor, e-mail: sanja.bugarinovic@irmbor.co.rs

** This work is the result of the projects TR 34006 "Mechanochemical Treatment of Poor-quality Mineral Resources" and TR 34025 "Development of Ecological Treatment Methods of Harmful Substances Using Ferrate (VI) of Electrochemical Oxidation or Reduction," funded by the Ministry of Education, Science and Technological Development of the Republic of Serbia.
} 
to conditionally stable terrains. In places of unstable slopes, where the sediments are subject to erosion and slipping, these environments are converted from stable into conditionally stable terrains in notches [1].

Detailed geological explorations of carbonate on the site Spasina - Brdjani included a series of exploration works which among other things included the exploration drilling and mining works (exploration trenches).

For the needs of determining the Bond Work Index, six composite samples of limestone were selected (in designation KR-2 to KR-14). Table 1 shows the coordinates of corresponding drill holes.

Table 1 Coordinates of realized exploration drill holes

\begin{tabular}{|c|c|c|c|c|}
\hline \multirow{2}{*}{$\begin{array}{c}\text { Designation } \\
\text { of drill hole }\end{array}$} & $\mathbf{X}$ & $\mathbf{Y}$ & $\mathbf{Z}$ & \multirow{2}{*}{ Interval of drill hole } \\
\cline { 2 - 4 } & 4948845.900 & 6578222.810 & 327.08 & $10.00-40.50$ \\
\hline KR-2 & 4948990.670 & 6578212.520 & 331.88 & $6.00-36.00$ \\
\hline KR-3 & 4948959.360 & 6578388.030 & 329.22 & $6.00-30.00$ \\
\hline KR-6 & 4948981.690 & 6578503.420 & 330.01 & $3.00-30.30$ \\
\hline KR-9 & 4949024.580 & 6578742.280 & 325.67 & $3.00-34.00$ \\
\hline KR-13 & 4948970.650 & 6578870.220 & 320.67 & $5.60-30.00$ \\
\hline KR-14 & & & \\
\hline
\end{tabular}

\section{EXPERIMENTAL PART}

\subsection{Characterization of Samples}

Chemical analysis of samples from termined their chemical composition (Tadrill holes at subsequently intervals de ble 2).

Table 2 Chemical composition of limestone samples

\begin{tabular}{|c|c|c|c|c|c|c|}
\hline $\begin{array}{c}\text { Element, } \\
\text { \% }\end{array}$ & KR-2 & KR-3 & KR-6 & KR-9 & KR-13 & KR-14 \\
\hline $\mathrm{SiO}_{2}$ & $0.92-1.72$ & $0.50-1.22$ & $0.50-0.80$ & $1.00-1.50$ & $1.97-3.85$ & $0.10-0.89$ \\
\hline $\mathrm{CaO}$ & $53.85-54.48$ & $53.04-54.38$ & $52.30-53.56$ & $52.98-53.67$ & $52.26-53.8$ & $54.35-55.31$ \\
\hline $\mathrm{Al}_{2} \mathrm{O}_{3}$ & $0.28-0.53$ & $0.21-0.36$ & $0.43-0.62$ & $0.38-0.59$ & $0.32-0.57$ & $0.46-0.66$ \\
\hline $\mathrm{Fe}_{2} \mathrm{O}_{3}$ & $0.30-0.44$ & $0.24-0.30$ & $0.26-0.40$ & $0.24-0.57$ & $0.30-0.47$ & $0.27-0.38$ \\
\hline $\mathrm{FeO}$ & $<0.1$ & $<0.1$ & $<0.1$ & $<0.1$ & $<0.1$ & $<0.1$ \\
\hline $\mathrm{MgO}$ & $0.52-0.59$ & $0.45-0.54$ & $0.26-0.29$ & $0.42-0.55$ & $0.41-0.46$ & $0.43-0.53$ \\
\hline $\mathrm{SO}_{3}$ & $0.04-0.28$ & $0.028-0.048$ & $0.07-0.143$ & $0.025-0.038$ & $0.06-0.14$ & $0.03-0.04$ \\
\hline $\mathrm{Na}_{2} \mathrm{O}$ & $0.035-0.065$ & $0.048-0.054$ & $0.049-0.061$ & $0.063-0.18$ & $0.048-0.07$ & $0.028-0.054$ \\
\hline $\mathrm{K}_{2} \mathrm{O}$ & $0.048-0.072$ & $0.040-0.047$ & $0.068-0.12$ & $0.049-0.12$ & $0.062-0.08$ & $0.062-0.098$ \\
\hline $\mathrm{MnO}_{2} 0.015-0.018$ & $0.019-0.030$ & $0.015-0.019$ & $0.012-0.039$ & $0.024-0.03$ & $0.018-0.034$ \\
\hline $\mathrm{P}_{2} \mathrm{O}_{5}$ & $0.044-0.048$ & $0.037-0.046$ & $0.041-0.046$ & $0.048-0.060$ & $0.046-0.05$ & $0.034-0.046$ \\
\hline $\mathrm{TiO}_{2}$ & $0.012-0.018$ & $0.012-0.017$ & $0.014-0.022$ & $0.011-0.022$ & $0.016-0.02$ & $0.017-0.026$ \\
\hline $\mathrm{S}$ & $0.017-0.11$ & $0.011-0.019$ & $0.028-0.057$ & $0.010-0.015$ & $0.024-0.05$ & $0.013-0.017$ \\
\hline $\mathrm{LOI}$ & $38.54-40.71$ & $39.89-40.95$ & $41.14-41.19$ & $41.20-41.44$ & $41.45-41.8$ & $41.70-42.40$ \\
\hline
\end{tabular}


The starting samples of limestone -6 samples (Figure 1) were dried at room temperature, and then on each of the samples the grain size distribution was determined accor- ding to the standard ISO 2591-1:1992. Preparation of limestone samples for testing included crushing in a closed cycle, and sieving on a sieve, mesh size of $3.35 \mathrm{~mm}$.
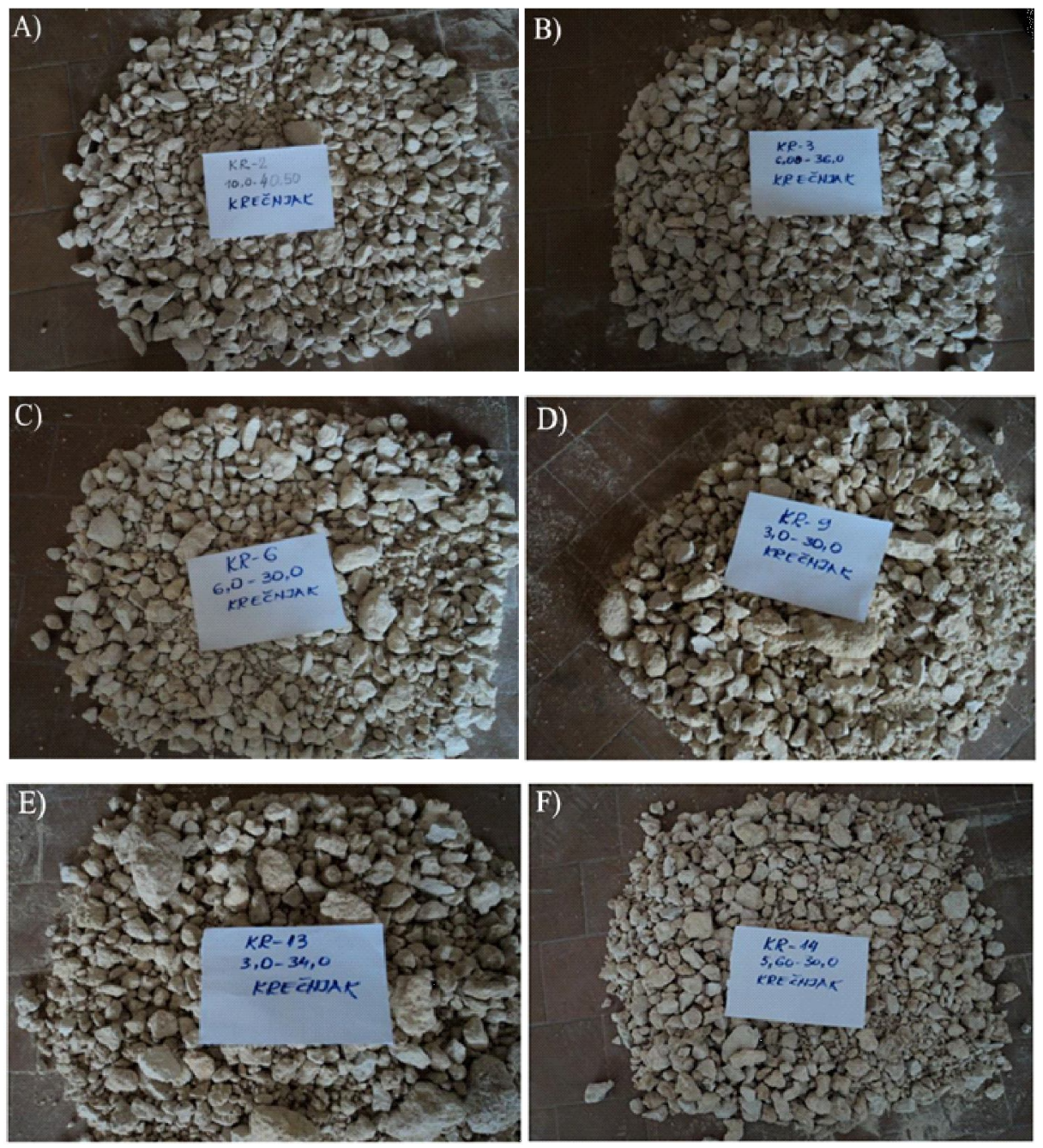

Figure 1 Starting samples of limestone from different drill holes

\subsection{Testing the Bond Work Index}

Testing the Bond Work Index on limestone samples was performed in the laboratory Bond ball mill, according to the established procedure [2]. Sieve is selected as a comparative sieve, mesh size $212 \mu \mathrm{m}$.
Figures 2 - 7 show the grain size distribution of crushed limestone samples (prepared for testing the Bond Work Index) as well as the grain size distribution of undersize of the comparative sieve. 
a)

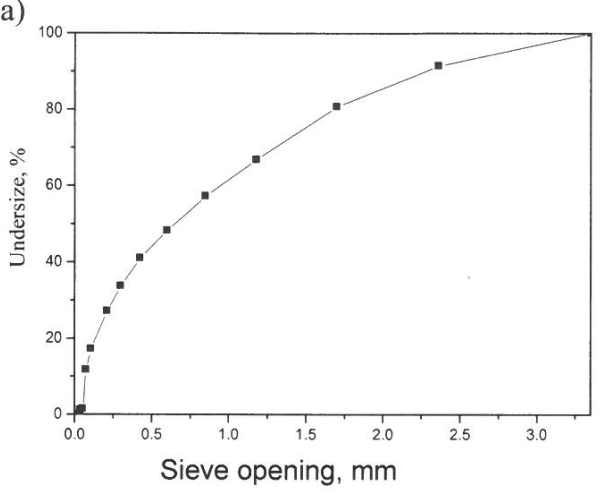

b)

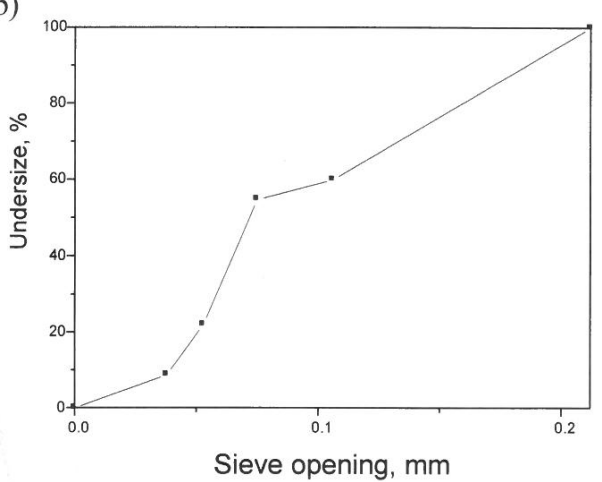

Figure 2 Grain size distribution of sample KR-2: a) crushed starting sample, b) undersize of comparative sieve

a)

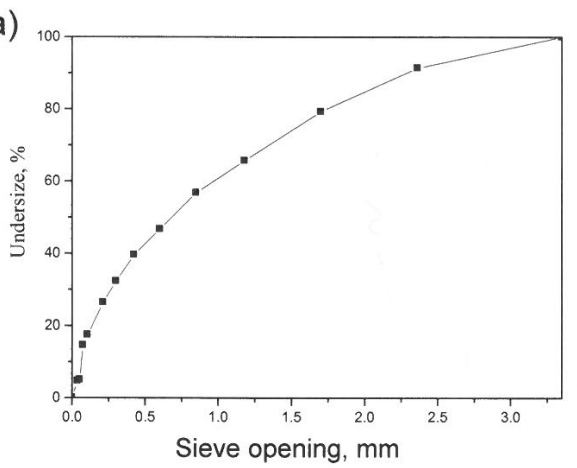

b)

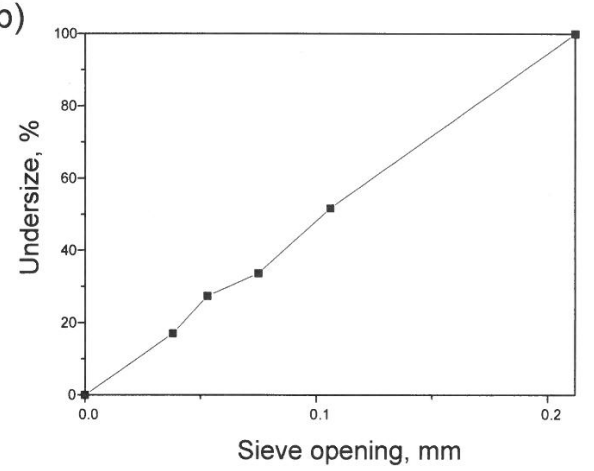

Figure 3 Grain size distribution of sample KR-3: a) crushed starting sample, b) undersize of comparative sieve

a)

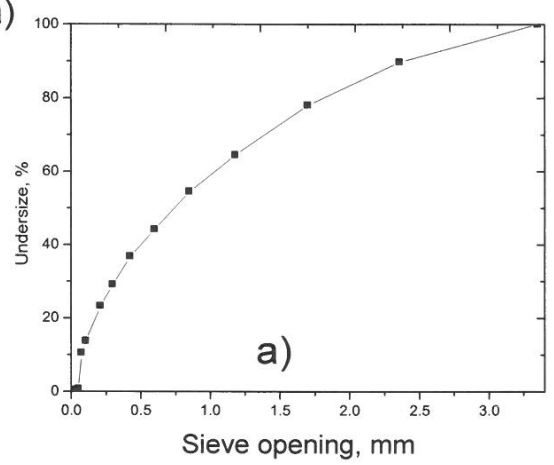

b)

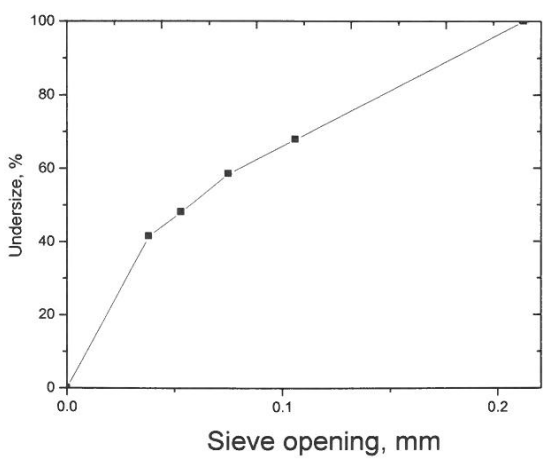

Figure 4 Grain size distribution of sample KR-6: a) crushed starting sample, b) undersize of comparative sieve 

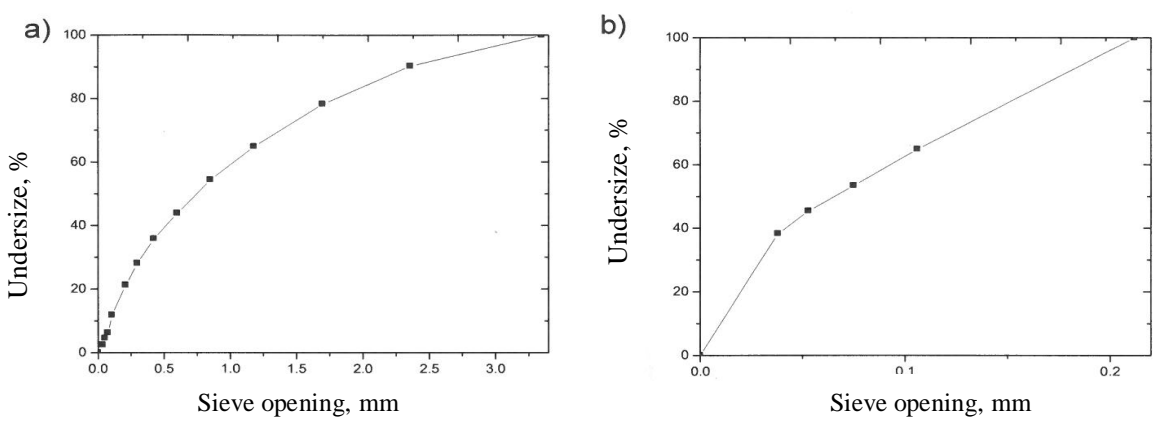

Figure 5 Grain size distribution of sample KR-9: a) crushed starting sample, b) undersize of comparative sieve
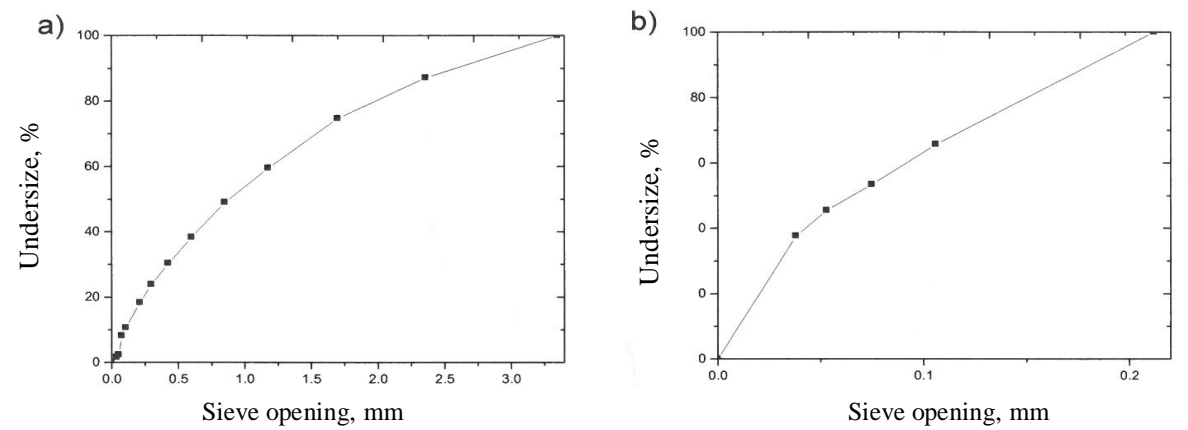

Figure 6 Grain size distribution of sample KR-13: a) crushed starting sample, b) undersize of comparative sieve
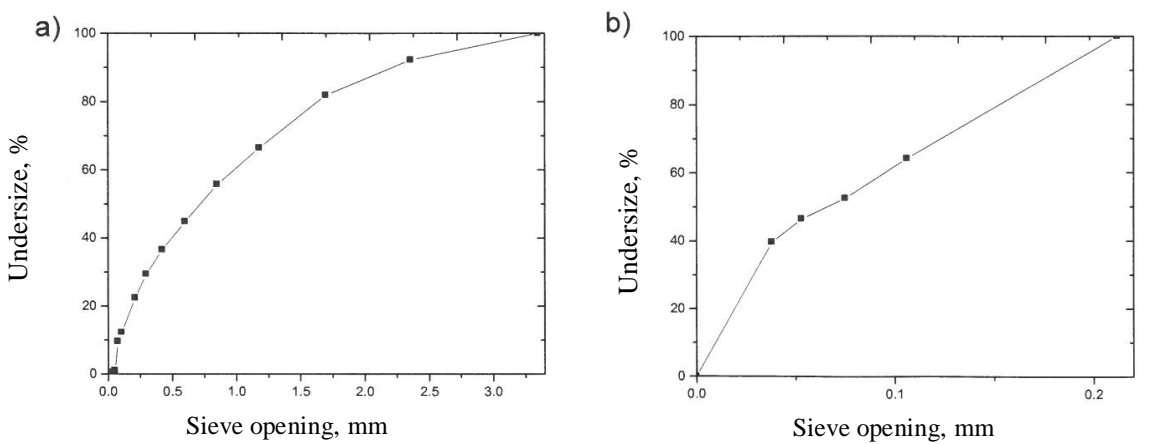

Figure 7 Grain size distribution of sample KR-14: a) crushed starting sample, b) undersize of comparative sieve

\section{RESULTS AND DISCUSSION}

The Bond Work Index was calculated according to the formula:

$W_{i}=1.1 \cdot \frac{44.5}{P_{k}^{0.23} \cdot G^{0.82} \cdot\left(\frac{10}{\sqrt{P}}-\frac{10}{\sqrt{F}}\right)} \mathrm{kWh} / \mathrm{t}$
Where:

$\mathrm{Pk}$ - mesh size of comparative sieve, $\mu \mathrm{m}$

$\mathrm{G}$ - new-created undersize per one revolution of mill, g/rev.

$\mathrm{P}-$ mesh size through which $80 \%$ of undersize of comparative sieve passes, from the last experiment, $\mu \mathrm{m}$ 
F - mesh size through which $80 \%$ of starting sample passes whose the Bond Work Index is determined, $\mu \mathrm{m}$.
Table 3 shows the obtained values of the Bond Work Index for 6 tested limestone samples.

Table 3 Characteristic parameters and the Bond Work Index for limestone samples

\begin{tabular}{|c|c|c|c|c|c|c|}
\hline Samples & KR-2 & KR-3 & KR-6 & KR-9 & KR-13 & KR-14 \\
\hline Pk, $\mu \mathrm{m}$ & 212 & 212 & 212 & 212 & 212 & 212 \\
\hline G, g/rev. & 5.553 & 3.523 & 5.601 & 4.645 & 5.358 & 5.438 \\
\hline P, $\mu \mathrm{m}$ & 159 & 167 & 147 & 152 & 150 & 153 \\
\hline F, $\mu \mathrm{m}$ & 1681 & 1735 & 1800 & 1780 & 1960 & 1620 \\
\hline $\mathrm{Wi}, \mathrm{kWh} / \mathrm{t}$ & 6.375 & 9.526 & 5.901 & 7.059 & 6.104 & 6.360 \\
\hline
\end{tabular}

The present test results (Table 3) indicate that the value of the Bond Index ranges between 5.9 and $6.4 \mathrm{kWh} / \mathrm{t}$. It can be seen that the deviations, which means slightly higher values of the Bond Work Index were realized in samples with designations K-R 3 and KR-9, 9.526 and $7.059 \mathrm{kWh} / \mathrm{t}$, respectively. The increased value of the Bond Work Index in these samples is explained by the presence of white-yellow limestone cores and increased content of magnesium. The correlation between the Bond Work Index and spatial position of exploratory drill holes and the deposit was established in this case.

\section{CONCLUSION}

The site Spasine - Brdjani is characterized by limestone and associated sediments belonging to the Middle Miocene of Central Paratetis - Baden and Sarmatian, then Quaternary formations - deluvial and proluvial sediments. In the engineering - geological terms, this site is characterized by a complex of carbonate of different physical and mechanical properties.

The values of the Bond Index mainly ranges between 2 and 3 with certain deviations. Therefore, the samples KR-2, KR-14 and R-14 are characterized by the Bond Index higher than 3 due to the presence of interlayers of alevrolyte, or high concentration of calcified fossils. On the other side, large presence of dusty component in the sample R-13 resulted in a very low value of its Bond Work Index. The explicit relationship between the spatial position of drill holes and the Bond Work Index was not established.

Determined values of laboratory testing the Bond Index range between 5.9 and 6.4 in limestone samples. Slightly higher values of the Bond Work Index were realized in samples with designations KR-3 (interval 6.0036.00) and KR-9 (interval 3.00-30.30) and the same amount to 9.526 and $7.059 \mathrm{kWh} / \mathrm{t}$, respectively. The increased value of the Bond Work Index is explained by the presence of white-yellow limestone cores in these samples (especially in sample KR- 3 (interval 6.00-36.00) as well as in a sample with designation KR-9 (interval 3.00-30.30) with increased content of magnesium.

\section{REFERENCES}

[1] Group of authors, Report on Detailed Geological Explorations of Carbonate in the Site Spasine - Brdjani near Ugljevik, MMI Bor, 2014, 37 p. (in Serbian)

[2] Magdalinović, N., Comminution and Grading of Mineral Raw Materials, Publisher: TF Bor, 1985, 177 p. (in Serbian) 